\title{
Understanding the "Punjab Problem"
}

\section{Author(s): Gurharpal Singh}

Source: Asian Survey, Vol. 27, No. 12 (Dec., 1987), pp. 1268-1277

Published by: University of California Press

Stable URL: https://www.jstor.org/stable/2644634

Accessed: 21-06-2019 12:38 UTC

\section{REFERENCES}

Linked references are available on JSTOR for this article:

https://www.jstor.org/stable/2644634?seq=1\&cid=pdf-reference\#references_tab_contents You may need to log in to JSTOR to access the linked references.

JSTOR is a not-for-profit service that helps scholars, researchers, and students discover, use, and build upon a wide range of content in a trusted digital archive. We use information technology and tools to increase productivity and facilitate new forms of scholarship. For more information about JSTOR, please contact support@jstor.org.

Your use of the JSTOR archive indicates your acceptance of the Terms \& Conditions of Use, available at https://about.jstor.org/terms

University of California Press is collaborating with JSTOR to digitize, preserve and extend access to Asian Survey 


\section{UNDERSTANDING THE "PUNJAB PROBLEM"}

\section{Gurharpal Singh}

Few subjects since the Emergency in India (1975-77) have commanded such attention as recent developments in Punjab: specialists and nonspecialists alike have felt the need to comment on the events that preceded and followed the Indian Army's Operation Blue Star in June 1984. The purpose of this paper is not to add to this output, but rather to distinguish and evaluate the various explanations that have been offered for what is commonly referred to as the "Punjab problem." Such an exercise is unlikely to be comprehensive or satisfactory, but given the confusion that characterizes many of the accounts, its value would appear to justify the liberties taken. In this effort, I have divided the literature into five groups: Sikh nationalism, conspiracy theories, primacy of regional factors, primacy of national factors, and Marxist interpretations. These headings, it is stressed, are neither exclusive nor exhaustive; at best they provide divisions of convenience.

\section{Sikh Nationalism}

Sikh nationalism has been isolated as the main explanatory variable by one group of commentators. Writing in 1974, Brass observed that "of all the ethnic groups and peoples of north India, the Sikhs come closest to satisfying the definition of a nationality or a nation." The achievement of a "cohesive Sikh identity," he added, had at times the "appearance of an invincible, solidary, national force." 1 But these compulsions towards nationhood, particularly after 1947, were contained by the parameters of linguistic regionalism set by the new Indian national leadership and its alliance with secular Sikh political elites who successfully divided the com-

Gurharpal Singh recently received the Ph.D. degree from the London School of Economics. He is currently unemployed.

(C) 1987 by The Regents of the University of California

1. Paul R. Brass, Language, Religion and Politics in North India (London: Cambridge University Press, 1974), p. 277. 
munity and supported the formation of a Punjabi Suba..$^{2}$ By the early 1980s, so the argument goes, this delicate equipoise no longer existed; the Dharam Yud morcha (1982-84), whether by default or design, reopened the Sikh national question, and in the process became a "freedom movement," 3 a Sikh revolution in the making. Seen in this light, Blue Star was not a security operation but a clash of two nations, the first "war for Khalistan." 4

Although these interpretations either highlight the modernism of Sikh nationalism as a yearning to be a part of the international community of nation-states, or suggest that its objectives might fall short of statehood, both concur that the current "national revival" is predicated on four types of discrimination perceived by the Sikh community: constitutional, religious, economic, and social. The rise of Bhindernwale, a charismatic leader who did not share the political culture of traditional Akalis, provided a critical catalyst in beginning the process of transforming this consciousness of a discriminated minority into the consciousness of a nation. ${ }^{5}$

Thus as the Dharam Yud morcha became enmeshed in futile negotiations, "a freedom movement always lurked at the edges because of the Sikh cultural and religious tradition that they were a sovereign people."6 Moreover this movement possessed an overarching ideology in fundamentalism that entrapped the traditional Akali leadership and sought to demonstrate the individuality of Sikhism. By counterposing a new world view, fundamentalism gradually undermined the existing ground of moderate Akali politics-electoralism, a lubricating corruption, and participation in the regional political system. ${ }^{7}$ But if the fundamentalist vision drew its inspiration from the Sikh achievements of the 18th century, its objective was essentially modern: to recreate a unit in which the Sikh community is a true repository of political power. In short, the Sikh nationalist wore many disguises; publicly, even Bhindernwale remained ambivalent on Khalistan.

2. Cf., Joyce Pettigrew, "A Description of the Discrepancy Between Sikh Political Ideals and Sikh Political Practice," in Myron J. Aronoff, ed., Political Anthropology Yearbook I (New Brunswick, N.J.: Transaction Books, 1980), pp. 152-192.

3. Joyce Pettigrew, "Take Not Arms Against Thy Sovereign: The Present Punjab Crisis and the Storming of the Golden Temple," South Asia Research, 4:2 (November 1984), p. 102.

4. M. J. Akbar, India: the Siege Within (New York: Viking Penguin, 1985), p. 209.

5. Sikh Youth Movement, The Sikhs and Recent Political Developments in India (Birmingham: 1984), pp. 41, 46-57; K. R. Bombwall, "Ethno-nationalism," Seminar, 294 (February 1984), pp. 44-51.

6. Pettigrew, "The Present Punjab Crisis," p. 111.

7. Angela Dietrich, "The Khalsa Resurrected: Sikh Fundamentalism in the Punjab," in Lionel Caplan, ed., Studies in Religious Fundamentalism (forthcoming). 


\section{Conspiracy Theories}

In sharp contrast to the above interpretations are what I have termed conspiracy theories. Put simply, they assert that the events that climaxed in June 1984 were the handiwork of those conspiring to dismember India by external aggression and internal extremism through the use of terror. The White Paper on the Punjab agitation published by the Indian government provides an illustrative example.

The essence of the problem in Punjab was not the demands put forward by the Akali Dal . . . but the maturing of a secessionist and anti-national movement. The Akali Dal leadership allowed the initiative and control over the agitation to pass out of their hands [to the secessionists and terrorists]. . . .

The terrorists escalated their violence. With each passing day the situation worsened. The subversive activities of groups inside the Golden Temple had assumed menacing proportions in the context of India's security. The influence of external forces, with deep-rooted interest in the disintegration of India, was becoming evident. The Government was convinced that this challenge to the security, unity and integrity of the country could not be met by the normal law and order agencies at the disposal of the State. It was in these circumstances that the decision was taken to call the army in. ${ }^{8}$

The White Paper's reluctance to detail the nature of "external forces"beyond a catalogue of Sikh nationalist organizations in Western Europe and North America-is not shared by Balraj Madhok, an ideologue of the Bharatiya Janata Party (BJP). For him, the roots of the "Punjab problem" lie in the "Muslim connection." "Muslim imperialism" led by Pakistan, argues Madhok, had attempted to divide Sikhs and Hindus-the Sikhs being a "militarised" wing of Punjab's Hindu society. ${ }^{9}$ Interestingly, Madhok proposes a novel solution to the "Punjab problem": the restoration, by force, of Lahore as the new capital of Punjab, thus resolving the territorial dispute over Chandigarh and recreating "emotional unity" between Sikhs and Hindus. ${ }^{10}$

Conspiracy theories also dominate explanations of Mrs. Gandhi's assassination. Ironically, though these have produced highly imaginative (and contradictory accounts), few writers have noted two obvious conspiracies: the attempted suppression by the government of the Citizens for Democracy publication, Report to the Nation: Oppression in Punjab, and the official inquiry into the assassination.

8. White Paper on the Punjab Agitation (Government of India: 1984), p. 3.

9. Balraj Madhok, Punjab Problem: The Muslim Connection (New Delhi: Hindu World Publications, 1985), p. vi.

10. Ibid., p. 150 . 


\section{Primacy of Regional Factors}

More serious studies have focused on developments in Punjab in an effort to identify general factors responsible for the present crisis. While most accept the importance of the ethnic cleavage between Hindus and Sikhs in shaping the creation of a Punjabi Suba, there is disagreement on the reasons for the collapse of the state's consociational political framework of the 1960s and 1970s.

Robin Jeffrey concentrates on the modernizing impact of the Green Revolution. For him, it accelerated the emergence of mass society: faceto-face village communities disintegrated; urbanization, consumerism, and mass literacy inflated expectations; ethnic identities became firmer emblems of occupational competition; rootlessness, alienation, and graduate unemployment nurtured messianic tendencies, especially fundamentalism; and, above all, a revolution took place in communication, particularly political communication. Social change outpaced familiar political practices and the ability of institutions to regulate them. Politicians accustomed to factional intrigues among elites now became "adrift on a sea of mass politics." In fact, they responded to these changes by launching "a desperate game in which few holds were barred." "Modernisation," asserts Jeffrey, "played a large part in shaping the Sikh unrest (represented in its extreme form in the demand for a sovereign state) which ultimately led to the storming of the Golden Temple, Mrs. Gandhi's assassination and the 'communal violence' that ripped cruelly through New Delhi and other northern Indian cities in November 1984."11

Another integrated approach is presented by Murray Leaf for whom the Green Revolution also provides a point of departure. The "Punjab problem," he argues, represents a choice between a pluralistic pattern of economic and political development favored by the Akali Dal and a Sovietized model of political economy followed by the state's-and the nation's-Congress administrations. The former stands for decentralization, ethnic and religious pluralism, and the use of ethical incentives to promote development; the latter, a quasimonopolistic party-government relationship, industrial domination of agriculture, and a distributionist socialist philosophy. Accordingly, the Akali agitation that crystallized around the Anandpur Sabha Resolution (ASR) should be interpreted as an attempt to create a new developmentalist order. The "Punjab crisis," Leaf concludes, "has not, fundamentally, been a clash between Sikhs and Hindus, nor between Sikhs and Indira Gandhi. ... It has been a clash between two

11. Robin Jeffrey, What's Happening to India? Punjab, Ethnic Conflict, Mrs. Gandhi's Death and the Test for Federalism (Basingstoke: Macmillan 1986), esp. pp. 8, 2. 
visions of the future and of India's proper political and social constitution. The basic questions remain unanswered." 12

The comprehensive outlooks of Jeffrey and Leaf are not shared by the rest of the regionally-centered literature. Most of it is too repetitive and isomorphic for detailed consideration, but some of the areas examined need to be mentioned. They include: the impact of linguistic reorganization on the Akali Dal's electoral support; the subsequent change in political recruitment to the Akali Dal, in particular the displacement of urban Sikh leadership by Sikh Jats who are held to be the main beneficiaries of the Green Revolution; the Akali Dal's adoption of a broad political and development policy, symbolized by the ASR, to accommodate conflicting caste and group interests while retaining the mobilizatory appeal of religion; the demographic threat to Sikh majority status posed by the growth of migrant labor from other states; and the role of leading personalities, both within the Congress and the Akali Dal, in promoting ethnic conflict. ${ }^{13}$

\section{Primacy of National Factors}

Nearly all regionally inclined explanations make some reference to national developments. Indeed, at this point the value of the distinction between the former and the latter begins to diminish. Broadly, the nationally centered explanations can be divided into two: the role of Prime Minister Indira Gandhi's leadership and the collapse of the Congress Party, and the impact of modernization on the Indian political system. Mrs. Gandhi's role has been emphasized by one group of writers who argue that she deliberately created the "Punjab problem" in order to exploit it. Her reluctance to resolve the Akali agitation, it is alleged, was part of a calculated strategy to divide the Akalis into moderates and extremists while cultivating sympathy among a predominantly Hindu electorate. ${ }^{14}$ The prime min-

12. Murray J. Leaf, "The Punjab Crisis," Asian Survey, 25:5 (May 1985), pp. 475-489.

13. Pramod Kumar et al., Punjab Crisis: Context and Trends (Chandigarh: 1984); Harish K. Puri, "The Akali Agitation: An Analysis of Socio-Economic Bases of Protest," Economic and Political Weekly (January 22, 1983), pp. 113-118; Yogendra K. Malik, "The Akali Party and Sikh Militancy," Asian Survey, 26:3 (March 1986), pp. 345-362; Paul Wallace, "The Sikhs as a 'Minority' in a Sikh Majority State in India," Asian Survey, 26:3 (March 1986), pp. 363-377; Victor S. D'Souza, "Economy, Caste, Religion and Population Distribution: An Analysis of Communal Tension in Punjab," Economic and Political Weekly (May 8, 1982), pp. 783-792; M. S. Dhami, "Punjab and Communalism," Seminar, 314 (October 1985), pp. $25-38$.

14. See, for example, R. Kothari and G. Deshingkar, "Punjab: The Longer View," in Abida Samiuddin, ed., The Punjab Crisis: Challenge and Response (Delhi: Mittal Publications, 1985), pp. 622-626. 
ister thus portrayed herself as the defender of the Hindu community, and in turn, reversed the conventional, post-1947 relationship between the center and moderate Akalis/Sikhs. ${ }^{15}$

The need for Mrs. Gandhi to project herself in this way has also been linked to her emasculation of the Congress Party. Its nationwide, integrative, and bargaining function, it is suggested, had been on the decline since the early 1970s; Mrs. Gandhi's victory in 1980 hastened the process. ${ }^{16}$ After 1980 political power became further centralized in Delhi where "fawners and flatterers" 17 ruled supreme. Moreover, Mrs. Gandhi's domination over her party was reflected in the reappearance of a style that had characterized her Emergency years. It was a style that

served one supreme end: [to] smash all threats to the political power of the ruling coteries and the projection of the prime minister as the supreme. The perceived threats came not only from within the Congress Party itself, and from the Opposition, but also from trade unions, the press, the judiciary, the students, the tribals, the rural poor whenever they turned rebellious. In fact, the threats came from within the country and from without, from the CIA, China, Pakistan and all those who were unhappy with "India's progress" and wanted to "destabilise" India. ${ }^{18}$

Perhaps the greatest "threat" was posed by the prospects of an electoral defeat, hinted at by midterm elections in some states in 1982 and 1983. The "Punjab problem" was thus transformed into a "Sikh threat" that was nationalized and placed outside the bounds of practical politics.

An alternative way of reaching the same conclusion is to extend Jeffrey's mass society thesis, in a modified form, to the rest of India. The variables in the Punjab equation are changed: Hindus replace Sikhs; Mrs. Gandhi and her party, the grasping Akalis (though this time to retain power). The symptoms of rapid modernization are found inter alia in the growth of a new political culture, displacing the Nehruvian values by the criminalization of politics. ${ }^{19}$ Though Mrs. Gandhi, in the words of Shourie, made a

15. Dipankar Gupta, "The Communalising of Punjab," Economic and Political Weekly (July 13, 1985), pp. 185-190. See also the contributions in Amrik Singh, ed., Punjab in Indian Politics: Issues and Trends (Delhi: 1985).

16. Cf., W. H. Morris-Jones, "India-More Questions than Answers," Asian Survey, 24:8 (August 1984), pp. 809-816; and James Manor, "Anomie in Indian Politics: Origin and Wider Impact," Economic and Political Weekly, annual number (May 1983), pp. 723-725.

17. Mark Tully and Satish Jacob, Amritsar: Mrs. Gandhi's Last Battle (London: Cape, 1985), p. 219.

18. Kothari and Deshingkar, "Punjab," p. 623.

19. This effectively makes up the other half of Jeffrey's thesis of a mass society as applied to the rest of India, though it must be emphasized that he remains ambivalent on whether the Hindu community constitutes a hegemonic ethnic group. 
special contribution to the "enfeeblement" 20 of the state, she and her party merely reflected contemporary India, what Jeffrey calls its "new" self ${ }^{21}$-a rapidly developing country undergoing economic, social, and communication revolutions. Seen in this context, Mrs. Gandhi and the Congress party (like the moderate Akalis and their fundamentalist rivals) were hemmed in by the compulsions of competitive politics-their own rhetoric, the policies of the opposition parties, and the need to defend their constituency. And if the "Punjab problem" ultimately led to disaster, it was because the prime minister and her party rode the same political roller coaster as their principal rivals.

\section{Marxist Interpretations}

Finally, there are the Marxist interpretations, which mainly attempt to identify the interaction of three related issues: the "national question," the impact of economic policies in Punjab on the emergence of social classes, and the role of the Indian state. Most Marxist accounts of the "Punjab problem" proceed from the "national question," that is, the process of nationality formation in India as an integral part of the development of capitalism. $^{22}$ Included in this framework, with the usual dialectical contingencies and ambiguities, are operational definitions of classes, relations of production, and the state. Depending on the assumptions made, India is either categorized as a multinational country, with a concurrent or a desynchronized development of the various nationalities, or is held to possess an "Indian nationality" that is prior to, and transcends, "linguistic regionalism." 23 Thus, for the Communist party of India (Marxist) (CPI[M]), the distorted development of Punjabi nationality is the outcome of policies followed by the ruling party. According to the CPI(M), the Congress "perpetuated [and] exploited communal divisions," and it "never took a democratic stand ... on the language issue or Punjab's reorganisa-

20. Arun Shourie, "A Ruinous Tragedy," in Arun Shourie, et al., The Assassination and After (New Delhi: Roli Books International, 1985), p. 42.

21. Jeffrey, What's Happening to India?, p. 11.

22. T. V. Sathyamurthy, "Indian Nationalism and the 'National Question,' " Millenium, 14:2, pp. 172-194; V. D. Chopra et al., Agony of Punjab (New Delhi: Patriot Pub., 1984).

23. For differences on the Indian "national question," see Amalendu Guha, "The Indian National Question: A Conceptual Framework," Economic and Political Weekly (July 31, 1982), pp. PE2-PE12; Javid Alam, "Dialectics of Capitalist Transformation and National Crystallisation: The Past and the Present of the National Question in India," Economic and Political Weekly (January 29, 1983), pp. PE29-PE46; Bipan Chandra, Communalism in Modern India (Delhi: Vikas, 1984). 
tion."24 Sathyamurthy and Gill and Singhal ${ }^{25}$ offer similar readings, though emphasizing the Congress's role in appeasing factions within the "ruling classes." In contrast, Asrafjan, Chopra, et al., and the Communist party of India (CPI) present a different assessment. Inclined toward the primacy of "Indian nationality," and the pre- and postindependence role of the Congress in shaping it, they stress the perversion of Punjabi "linguistic regionalism" by communalism, in particular, Sikh communalism. ${ }^{26}$

Yet these differences betray strong similarities in identifying the nature of class relations in Punjab. All Marxists highlight the rapid increase in rural capital formation that began with the Green Revolution and coincided with the formation of a Punjabi Suba. The introduction of modern agricultural practices, they argue, led to peasant differentiation and the emergence of a class of "capitalist" farmers. This development, it is further asserted, sharpened contradictions between the capitalist farmers and the poor peasantry and agricultural laborers, and between the capitalist farmers and the all-India industrial bourgeoisie. Furthermore, in Punjab, these contradictions are said to have reinforced two other social cleavages-caste, in which Sikh Jats (capitalist farmers) intensified the exploitation of Mazbis and Ramdasis (agricultural laborers); and the urban-rural divide, in which the traditional ascendency of Hindu mercantile capital, established during the colonial period, was contested by the capitalist farmers.

Despite these commonalities, however, differences reappear in characterizing the pre-June 1984 Akali agitation. For Bains, Sathyamurthy, and Gill and Singhal, the agitation was directed at changing the balance of national economic power, held by the "monopoly bourgeoisie/monopoly capitalist/big industrial houses," in favour of the capitalist farmers. ${ }^{27}$ Asrafjan, Chopra, et al., and the CPI, on the other hand, disagree. The dynamics of the movement, they insist, were largely shaped by the communal ideology of the Akali Dal, its reluctance to abandon "confessional" politics in the quest for regional power.

24. Harkishan Singh Surjeet, Lessons of Punjab (New Delhi: 1985), p. 18.

25. Sucha Singh Gill and K. C. Singhal, "Genesis of the Punjab Problem: Its Historical Roots," Economic and Political Weekly (April 7, 1984), pp. 603-608; Sathyamarthy, "Indian Nationalism."

26. K. Z. Asrafjan, "Sovermennye sikhskie nacionalisticeskie tecenija v. Pendzabe," (Sikh Nationalist Trends in Punjab), Narody Azii i Afriki, 5 (1984); Chopra, et al., Agony of Punjab; Avtar Singh Malhotra, Save Punjab Save India (CPI: 1984).

27. Sucha Singh Gill and K. C. Singhal, "Farmers' Agitation: Response to Development Crisis of Agriculture," Economic and Political Weekly (October 6, 1984), pp. 1728-1732; and Hardial Bains, The Call of the Martyrs: On the Crisis in India and the Present Situation in the Punjab (London: 1985). 
These divisions are further evident in the contrasting evaluations of the role of the Indian state. Generally, ideological commitments and party affiliations determine the emphasis selected. For Banerjee, the "happenings in Punjab were not an isolated instance, but a symptom of the general ideological bankruptcy, brought about by the emergence of new sociopolitical forces unleashed by a lopsided development programme by the Centre."28 Bains also inveighs against the "big landlord/big capitalist" state, though adding that its ideological legitimation is underpinned by a skillful exploitation of the "Brahmanical order."29 Vanaik, too, draws attention to the "legitimation problem" of the Indian state, but for him this is connected with the political emergence of "intermediate castes" and the Congress's attempts to mobilize them under the new "hegemonising ideology" of "Hindu nationalism." 30 Chopra and others are again an exception, locating the "genesis of the Punjab problem" in the crisis of western "imperialism," its "neo-colonial" designs on India, and encouragement of Sikh extremism. ${ }^{31}$

\section{An Interim Conclusion}

The idea of a Sikh national revival, whether understood as a part of further ethnic consolidation or a drive toward statehood, fails to account for one significant fact: the relatively limited support for militants among the Sikhs in Punjab. These interpretations, in their extreme form, are only tenable if one proposes a nationalist's equivalent of "false consciousness," that is, Sikhs are unaware of their "true" interest and are manipulated, divided, and ideologically brainwashed by the central government. Likewise, the persistence of cross-cutting and overlapping economic, social, cultural, caste, and political interests of Sikhs and Hindus can only be denied by assertions that the two communities are monolithic entities, discretely divided and mutually at war. Yet despite the tragic events of 1984 and the continuing strife, a wholesale decoupling of these links has not occurred. Future polarization might lead in this direction, but there are equally sound reasons for believing the opposite.

The conspiracy theories present the most unconvincing interpretations. In many ways the products of imaginative minds, they have lost any credence they might have possessed with Operation Blue Star and the subsequent persistence of terrorism in Punjab. Indeed, it is not difficult to conjecture that a militaristic reading of the "Punjab problem" and its con-

28. Sumanta Banerjee, "Punjab," Economic and Political Weekly (July 7, 1984), p. 1019.

29. Bains, Call of the Martyrs, pp. 130-195.

30. Achin Vanaik, "India's Bourgeois Democracy," New Left Review, 154, pp. 55-82.

31. Chopra et al., Agony of Punjab, pp. 8-9, 94-130. 
tinual association with Pakistani machinations, might result in a conflict between India and Pakistan.

Regionally centered accounts, on the other hand, suffer from two major limitations: a tendency toward exaggeration and an overemphasis on the Sikhs. Jeffrey's mass society thesis is based on a few selected social indicators which do not warrant such a construction. Similarly, Leaf's general framework overlooks the contradictory aspects of the Akali Dal's demand for economic and political autonomy-especially in the nonagricultural sector, and the articulation of this demand in terms of ethnic exclusivitywhile stereotypically characterizing the regional and national Congress administrations. The other studies in this group, in contrast, are marked by a relative neglect of the Punjab Hindu's contribution to the "Punjab problem," a tendency to treat the Sikh community in isolation as an independent variable.

Some of the same shortcomings are present in interpretations that stress the primacy of national factors. The use of modernization theory, for example, though analytically clear, still requires empirical verification. Nonetheless, these interpretations are, as the post-June 1984 events have demonstrated, more comprehensive than the individualization of the subject in terms of Mrs. Gandhi's personality.

Finally, the Marxist interpretations are certainly the most comprehensive in integrating the various analytical levels of the "Punjab problem." This achievement, however, is obtained at the cost of much simplification and reification - of class, caste, party, and the state; of nationality, community, and regional loyalties; and of class and nonclass loyalties. With a few notable exceptions, nearly all of this literature belongs to the school of "vulgar Marxism."

Overall, the recent publications on the "Punjab problem" share several common shortcomings. There is a profusion of unclear definitions, assumptions, and ambiguities. Few attempts have been made to demarcate the relevant analytical levels of the issue. And almost all the studies mentioned are flawed by the lack of sufficient empirical data-from the conspiracy theories to Marxist class alignments, from the Sikh nationalist interpretations to the regional problems of the Akali Dal, and from the structural changes in the Indian political system to factional infighting in Punjab. Although many of the works examined filled an immediate need to explain dramatic events, their general contribution to an understanding of the subject remains limited. The "Punjab problem" still stands in need of a rigorous analysis. 